\title{
TATARISTAN'IN KUKMARA RAYONU MAMAŞİR KÖYÜNDE SABANTUY BAYRAMI
}

\begin{abstract}
ÖMER AKSOY*
Öz: Kazan Tatarları, İdil-Ural bölgesi olarak adlandırdığımız coğrafyada teşekkül eden kadim Türk medeniyetinin günümüzdeki en mühim temsilcilerindendir. İslam'1 ilk kez kabul eden Türk boyu olma özelliğine sahip olup İslam kültür dairesine girmesi ile birlikte Türk-İslam medeniyetinin en önemli temsilcileri ve taşıyıcıları arasında yer almıştır. Uzun yıllar bağımsız yaşayan Tatar Türkleri, Rus işgali ile birlikte siyasi bağımsızlığını kaybetmiş olsa da kültürlerini yaşamaya ve gelecek nesillere aktarmaya devam etmektedirler. Bu kadim kültürün en bilinen geleneksel bayramlarından biri de Sabantuy Bayramı'dır. Genel itibariyle Mayıs ayı sonu Haziran ayı başında Tataristan'ın Müslüman Tatarlar ile meskûn bölgelerinde her yıl coşku ile kutlanan bu bayram, özellikle Rusya bünyesinde, devlet yönetiminin zorla kültürleme politikaları karşısında geleneksel kültürlerini ve millî kimliklerini koruma mücadelesi veren Tatar Türkleri için millî bir sembol hüviyetinde olmuştur. Bu çalışmada öncelikle Sabantuy Bayramı'nın genel hususiyetleri, eski Türk inanç sistemleri ile olan bağları, bayramın Tatar Türkleri için taşıdığ 1 önem ve bayramın kültürel kimlik bağlamında nasıl bir sembol değeri taşıdığı ile alakalı bilgiler vereceğiz. Sonrasında ise Tataristan'da bulunduğumuz dönemde yapmış olduğumuz derleme çalışmaları kapsamında ziyaret ettiğimiz Kukmara rayonuna bağlı Mamaşir köyünde kutlanan Sabantuy Bayramı'nın Tatarlar tarafından ne şekilde kutlandığı ile alakalı gözlemlerimizi ve bu gözlemler neticesinde yapmış olduğumuz değerlendirmelerimizi aktaracağız.
\end{abstract}

Anahtar Sözcükler: Sabantuy, Kazan Tatarları, Tataristan, kültürel kimlik, Mamaşir köyü.

\section{Sabantuy Feast in The Mamashir Village District OF KuKMara OF TATARSTAN}

ABSTRACT: Kazan Tatars are the most important representatives of the ancient Turkish civilization in the Idyll--Ural region. They are the Turkish tribe that adopted Islam for the first time. With their acceptance of Islam, they became the most important representatives and carriers of the Turkish-Islamic civilization. Tatar Turks, who lived independently for many years, lost their political independence with the Russian occupation. Despite this, they continue to live their culture and transfer them to future generations. One of the most well known traditional holidays of this ancient culture is Sabantuy. It is celebrated with enthusiasm every year in the regions where Tatars live, usually in late May and early June, and is a national symbol especially for Tatar Turks

\footnotetext{
* Doç.Dr., Trakya Üniversitesi, Edebiyat Fakültesi, Türk Dili ve Edebiyatı Bölümü, aksoy2302@hotmail.com, ORCID: 0000-0001-9837-7567

(Yazının Geliș Tarihi/Received Date: 21.09.2020, Yazının Kabul Tarihi/Acceptance Date: 26.11.2020)
}

Doi: 10.47089/iuad.797850 
บค• ÖMER AKSOY

who struggle to protect their traditional culture and national identity in the face of forced cultural policies of the Russian administration. In this study, we will describe how Sabantuy was celebrated in the village of Mamashir, which we visited within the scope of the compilation studies during our time in Tatarstan. Beforehand, we will give information about the Sabantuy Festival, general characteristics, relations with the old Turkish belief systems, the importance of this feast for Tatars and what symbol it is in the context of cultural identity.

Key Words: Sabantuy, Kazan Tatars, Tatarstan, Mamashir village, cultural identity.

\section{Giriş: Sabantuy Bayramı ve Tatar Kültüründeki Yeri}

Sabontuy, Tatar Türklerinin en önemli geleneksel bayramlarından biridir. Kökenleri Kazan Tatarlarının İslam'1 benimsemesinden önceki dönemlere dayanan Sabantuy Bayramı, adından da anlaşılacağ1 üzere tarım kültürü ile ilişkilidir. Bayramın arkaik köklerini Tatarların ataları olan İdil Bulgarlarının 8 ve 9. yüzyıllarda yerleşik düzeni benimsemeye başlamaları ile ilişsilendirmek mümkündür. Sabantuy Bayramı, ekici kültürle ilişkili olarak bilhassa kırsal bölgelerde Tatar halkının toplanıp, yazın gelişini müzik ve oyunlar eşliğinde eğlenceler tertip ederek kutladığı bir bayramdır. Bayramın kutlandığı belirli bir gün olmamakla birlikte karların erimesi, doğanın uyanması ve hasat dönemi ile olan ilişkisinden kaynaklı olarak haziran ayında, yörenin ileri gelenlerinin uygun gördüğü bir tarihte kutlanmaktadır. Bu bayram vesilesiyle düzenlenen eğlenceler birkaç gün devam edebilmektedir. Günümüzde ise bu bayramın kutlanması kırsal bölgelerin sınırlarını aşmış ve Sabantuy şehir merkezlerinde de kutlanan resmî bir bayram hüviyeti kazanmıştır.

Sabantuy'un ekici kültür ile olan münasebetlerini göstermesi noktasında güzel bir örnek ise eski dönemlerde Sabantuy öncesinde çocuklara botka yani yulaf lapası ikram edilmesidir. Yine Tataristan'ın bazı bölgelerinde Sabantuy Bayramı Karga Botkası olarak adlandırılmaktadır. İlkbaharda karlar yerden kalkıp toprak göründüğünde, köyün ihtiyarlarının belirlediği gün çocuklar maniler eşliğinde ev ev dolaşıp bulgur, süt, yağ ve yumurta toplar, toplanan yiyeceklerden büyük bir kazan içerisinde botka pişirirlermiş. Bu botkanın tadına bakmak için köyün bütün çocukları ve kadınları toplanırmış. Herkes tabak-kaşık getirir ve ikram sonrası çeşitli oyunlar oynarlarmış. Botkayı kaşıklara alıp kargalar gibi zıplayarak, açılmış yerlere de saçı olarak kötü ruhları defetmek adına serperler imiş. Tarım toplumuna özgü bir çeşit kansız kurban örneği olan saçıların bu törenlerde uygulanmış olması, Sabantuy ile ekici kültür arasındaki ilişkiyi gözler önüne sermektedir (Zaripova Çetin 2017: 871).

Sabantuy Bayramı, bayram öncesi ve bayram esnasında yapılan şenlikler ve yarışmalar olmak üzere iki kısma ayrılmaktadır. İlk kısım bayram öncesinde yapılan hazırlıkları içermektedir. İkinci kısım ise bayram günü yapılan etkinliklerden müteşekkildir. Bayram hazırlıkları kapsamında yöre kadınları evlerini ve avlularını temizlerler. Bayram için yemekler hazırlar ve uzak bölgelerden gelecek olan misafirleri için hazırlıklar yaparlar (Zaripova Çetin 


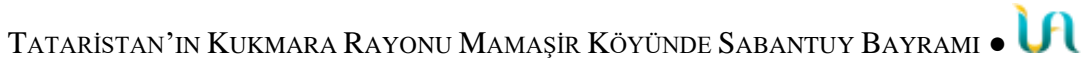

2017: 872). Kadınların yaptıkları yemeklerin bolluğu, hasadın bol olma temennisi ile doğru orantılıdır. Geleneksel toplumların doğa karşısındaki beklentilerinin karşılloğının kendi cömertlikleri nispetinde olduğu düşüncesi, Tatar Sabantuy'unda yapılan hazırlıklar ile kutlamalar esnasında verilecek hediyeler ve misafirlerin ağırlanması gibi durumlarda kendini göstermektedir. Yine bu hazırlık sürecinde, kutlamalar esnasında yapılan yarışmaları kazananlara takdim edilecek hediyeler temin edilmektedir. Bu hediyeler Sabantuy meydanının başköşesinde sergilenmekte ve yarışmaları kazananlara peyderpey takdim edilmektedir.

Törenlerin yapıldı ̆̆ı alana meydan adı verilmektedir. Köyün yakınında olan bu alanlar düzlük ve çayırdır. Tahta ve kütüklerle daire şeklinde insanların oturacakları biçimde çevrilen meydanın etrafını izleyiciler çevreler, ortada ise müsabakalar yapılmaktadır. Meydanın bir köşesinde kazananlara verilecek hediyelerin istiflendiği alan vardır. Bu alan ayrıca imamın açılış duasını yaptığı, konuşmacıların konuşmalarını, sunucuların ise yarışmaları ve yarışmacıları takdim ettiği yerdir.

Sabantuy kutlamalarının yapıldığı alan ile alakalı kayıtlara geçen arkaik uygulamalardan biri Sabantuy'a hazırlık aşamalarından birisi olarak meydanın etrafının saban ile daire şeklinde çizilmesi suretiyle kötü ruhlara ve çeşitli olumsuz durumlara karşı koruma altına alınmasıdır. Kayum Nasırî, Kazan Tatarlarının Ișanuları hem Yolaları (Kazan Tatarları'nın İnanışları ve Gelenekleri) adlı eserinde saban ile daire çizme geleneğinin eskiden insanlara ve hayvanlara zarar veren hastalıklar sırasında da uygulandığını ifade eder (Nasıri 1880: Zaripova Çetin 2017: 871). Ayrıca "Tılsımlı Daire" (Tılsımlı Tügerek) adı verilen Tatar inanışına göre yolda kalındığında veyahut dağ, çöl-bozkır, orman gibi ıssız ve tehlikeli yerlerde geç vakte kadar kalındığı durumlarda düz bir yer seçilir. İçerisinde bulunulan alanın çevresi, ucu ince bir ağaç parçası veya bıçak ile daire içerisine alınacak biçimde çizilir, bilinen dualar okunur ve uyunur. $\mathrm{Bu}$ şekilde yapıldığ 1 takdirde hiç kimse dokunmaya cesaret edemez ve insan, kendi evindeymiş gibi rahat bir şekilde uyur. Hatta daha da güvenli olması için dairenin içine bıçak veya hançer saplanır ya da başka bir metal eşya konabilir. Zira inanışa göre kötü ruhların metalden korktukları düşünülmektedir (Tatar Mifları (I. Kitap) 1996: 356) $)^{1}$.

Buna benzer uygulamalar Türk boyları arasında oldukça yaygındır. Tatarlar gibi İdil-Ural bölgesinin kadim topluluklarından olan Çuvaşların Timer Karta (Demir Avlu) adını verdikleri ritüelde benzer bir uygulama ile karşılaşmaktayız. Buna göre daire içerisine alınan bir nesne veyahut bölge, kötü ruhlara ve çeşitli

\footnotetext{
1 Birçok farklı kültürde var olan bu uygulamanın en eski varyantı Gılgamış destanında karşımıza çıkmaktadır. Destanda arkadaşı Enkidu ile sedir ormanının koruyucusu Humbaba'yı öldürmek için yolculuğa çıkan Gılgamış, bu yolculuk esnasında 6 kez uykuya dalmıştır. Gılgamış, uyumadan evvel Enkidu tarafından bir yere yatırılmakta, yattığı alanın çevresine büyülü bir çember çizilmekte ve Gılgamış'ın üzerine dualar okunup üflenmektedir. Bu sayede Enkidu Gılgamış’1 çeşitli kötülükler ve olumsuz durumlar karşısında koruma altına almaktadır (Gılgamış Destanı 2016: 37-40).
} 
Uొ• ÖMER AKSOY

olumsuz durumlara karşı koruma altına alınmaktadır. Kız sabanı adı verilen Çuvaş ritüelinde de bu uygulamanın başka bir örneğini görmekteyiz. Köy hayvanlarının salgın hastalık neticesinde ölmeye başlaması üzerine köylüler, Timer Karta ritüelinin bir parçası kabilinde klz sabanı yapar; köyün etrafını dolaşması için kırk bir kız, köyden bulgur ve yumurta toplayıp tarla kapısının önüne götürerek lapa ve yumurta pişirmesi için de bir ihtiyar seçerler. Kızlar, lapa yapılan yerden başlayarak köyün etrafını sabanla çizerler. Sabanın köyün etrafında sürülmesi neticesinde sabanın toprağa bıraktığı çizgi ölüm, hastalıklar ve zararlı güçlere karşı simgesel bir duvar oluşturur (Yavuz 2019: 196-197). Bu uygulama, Eliade'nin tabiriyle mekânı "merkez simgeciliği" ile kutsallıkla bağlantılı olarak merkezî bir yapı içinde algılama biçiminin bir yansımasından başka bir şey değildir. Gökle doğrudan iletişimin olabilirliği inancına bağlı olarak mikro kozmos düzeyinde bu iletişim çizilen daire ile temsil edilir (Eliade 2017: 331; Eliade 2017: 25-30). Bu, aynı zamanda Tanrısal eylemin yenilenmesidir. Geleneksel toplumun, duygusal büyü bağlamında istenilen etkiyi temsil veya taklit ederek onu gerçekten meydana getireceğini varsaymasıdır (ateş yakarak güneş çıkarma, ürünün büyümesini taklit ederek hasat almayı umma vb.) (Frazer 2004: 276). Tanrısal eylemin temsili ve taklidi ile insanlar, kendilerini kötü ruhlardan, hasatlarını ve ürünlerini ise olumsuz biçimde etkileyecek kötülüklerden koruma gayesi ile Sabantuy alanını saban ile daire şeklinde çizmektedir. Sabantuy Bayramı'nın hemen ardından Tatarların ekinlerini ekmeleri, sabandan dönenleri kırk kapısı yanında beklemeleri ve üzerlerine bol su dökmeleri (Zaripova Çetin 2017: 876) de yine bir çeşit duygusal büyü örneği olup yağmurların yağması, kuraklık olmaması ve ürünlerinin olumsuz anlamda etkilenmemesi için yapılan bir çeşit korunma yöntemidir.

Sabantuy kutlamaları öncesinde birçok farklı ritüel yapılmakta, kutlamalar çerçevesinde ise gün boyunca çeşitli yarışmalar düzenlenmektedir. Bunlar içerisinde at yarışı, güreş, güzel şarkı söyleme, halat çekme, direğe tırmanma, ağırlık kaldırma vb. yer almaktadır. Yarışlar sonucunda bayramdan önce toplanan hediyeler kazananlara verilmektedir. Tataristan'ın farklı bölgelerinde düzenlenen Sabantuy şölenleri genel itibariyle tüm Tatar boyları tarafından büyük benzerlikler ihtiva edecek biçimde kutlansa da Sabantuy kutlamalarının her bölgeye özgü hususiyetleri bulunmaktadır. Bu farklılıklar Tatar araştırmacılar tarafından birkaç varyant olarak sinıflandırılmıştır. Ünlü Tatar etnograf R. Urazmanova'nın yaptığı tasnife göre en karmaşık olan birinci varyant; Mamaşir, Kukmara, Saba, Arça ile Tataristan'ın doğu ve güneydoğu ilçelerinde kutlanan ve kutlamaların bir gün ile sınırlı kalmayıp birkaç gün devam ettiği Sabantuy bayramlarıdır. Bu Sabantuy kutlamalarının tarihi, karların erimesi ile köyün aksakalları yani ileri gelenleri tarafından belirlenmektedir. $\mathrm{O}$ günde çocuklar, yukarıda da ifade ettiğimiz gibi köydeki tüm evleri dolaşarak kepek (tahıl kepeği), süt, yağ ve yumurta toplarlar. Tecrübeli bir kadın, su kenarında veya kendi evinde bu toplanmış erzaktan karga botkası hazırlayıp çocuklara ikram eder. Ertesi gün sabah erkenden çocuklar tekrar evleri dolaşarak boyalı yumurta toplarlar. Aynı gün öğleden sonra ata binmiş delikanlılar yumurta toplamaya, Tatarların tabiri ile 


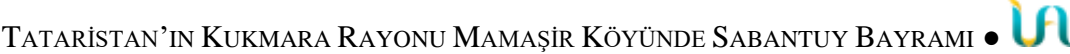

"sören sugarga" çıkarlar. Bazen buna yaşı ilerlemiş olanlar da katılabilir. 'Sören könnere' (hediye toplama) günleri yaklaştığında gençler köyde hediyelik eşya toplamaya başlarlar. Köylü hanımlar önceden hazırladıkları yün çorap, yumurta, mendil ve çeşitli eşyaları verirler. Ertesi gün farklı müsabakaların yapılması için Sabantuy meydanına toplanılır. Müsabakalar at yarışları ile başlar. Sonra güreş, koşu veya farklı geleneksel ve yöresel oyunlarla kutlamalar devam eder. Köy ahalisinden toplanan hediyeler müsabakaları kazananlara verilir. Aynı günün akşamında gençler için eğlence tertiplenir. Eğlencede şarkılar, türküler söylenir; farklı oyunlar oynanır. R. Urazmanova'nın tasvirine göre Sabantuy'un en karmaşık varyantına ait olan kutlamaları şu şekilde sıralayabiliriz: 1) Çocuklar tarafindan toplanan erzaktan onlar için lapa yapilması (Zere Botkasi), 2) Çocukların boyalı yumurta toplamaları, 3) Ata binmiş delikanlıların yumurta toplamaları ve su kenarında veya ormanda yemeleri, 4) Farklı ve özgün elbiseler giyen erkekler tarafindan yumurta toplanması, 5) Sabantuy için hediyeler toplanmas1, 6) Meydandaki müsabakalar, 7) Gençlerin akşam eğlenceleri (Urmançe 2009: 301).

Sabantuy'ın Baltaç ve Arça ilçelerinde gerçekleştirilen ikinci varyantı daha sadedir. Başlıca kutlamalar şu aşamalardan oluşmaktadır: 1) Sabantuy bayramından yaklaşık 10 gün önce düzenlenen, gençlerin "Atın bacaklarını ısıtma" adını verdikleri at yarışı, 2) Çocukların boyalı yumurta toplamaları, 3) Sabantuy müsabakalarında birinciliği alanlar için hediye toplanmasi, 4) Sabantuy meydanında Sabantuy Bayramı günü yapılan kutlamalar, 5) Gençlerin akşam eğlenceleri. Tataristan'ın Yeşel ve Biyektav ilçelerinde karılaştığımız başka bir varyantta ise köyün yaşlı erkekleri yanlarına tavuk yumurtaları alarak mezarlığa giderler. Orada namaz kılıp dua ederler. Toplanan yumurtalar imama verilir. Köylü kadınlar aynı gün komşu kadınları davet ederek ikramlarda bulunurlar. Bu törenler de şu şekilde sıralanır: 1) Yaşlı erkeklerin mezarlığa gitmeleri, 2) İki-üç erkek tarafindan Sabantuy hediyeleri toplanmasi, 3) Sabantuy'a gelen çocuklara boyalı yumurta dağıtılması, 4) Meydan eğlenceleri, 5) Gençlerin yemek yemeleri, 6) Gençlerin akşam eğlenceleri (Urmançe 2009: 302). Bu farklılıklardan başka, işlevleri aynı kalmakla ve aynı hisleri uyandırmanın yanı sıra her Sabantuy'un kendine özgü yönleri bulunmakta, farklı müsabakalar ve eğlenceler her bölgede farklılıklar gösterebilmektedir.

\section{Mamaşir Köyünde Sabantuy Bayramı}

Mamaşir köyü Kukmara ilçesine bağlı olup Kirov eyaleti sınırında, Burets Nehri kıyısında yer almaktadır. Kazan'a yaklaşık $160 \mathrm{~km}$ uzaklıktadır. Bizim Mamaşir'e ulaşımımız 2 saatlik bir tren yolculuğunun ardından 15-20 dakikalık araba yolculuğu neticesinde gerçekleşmiştir. 


\section{Uิ• ÖMER AKSOY}

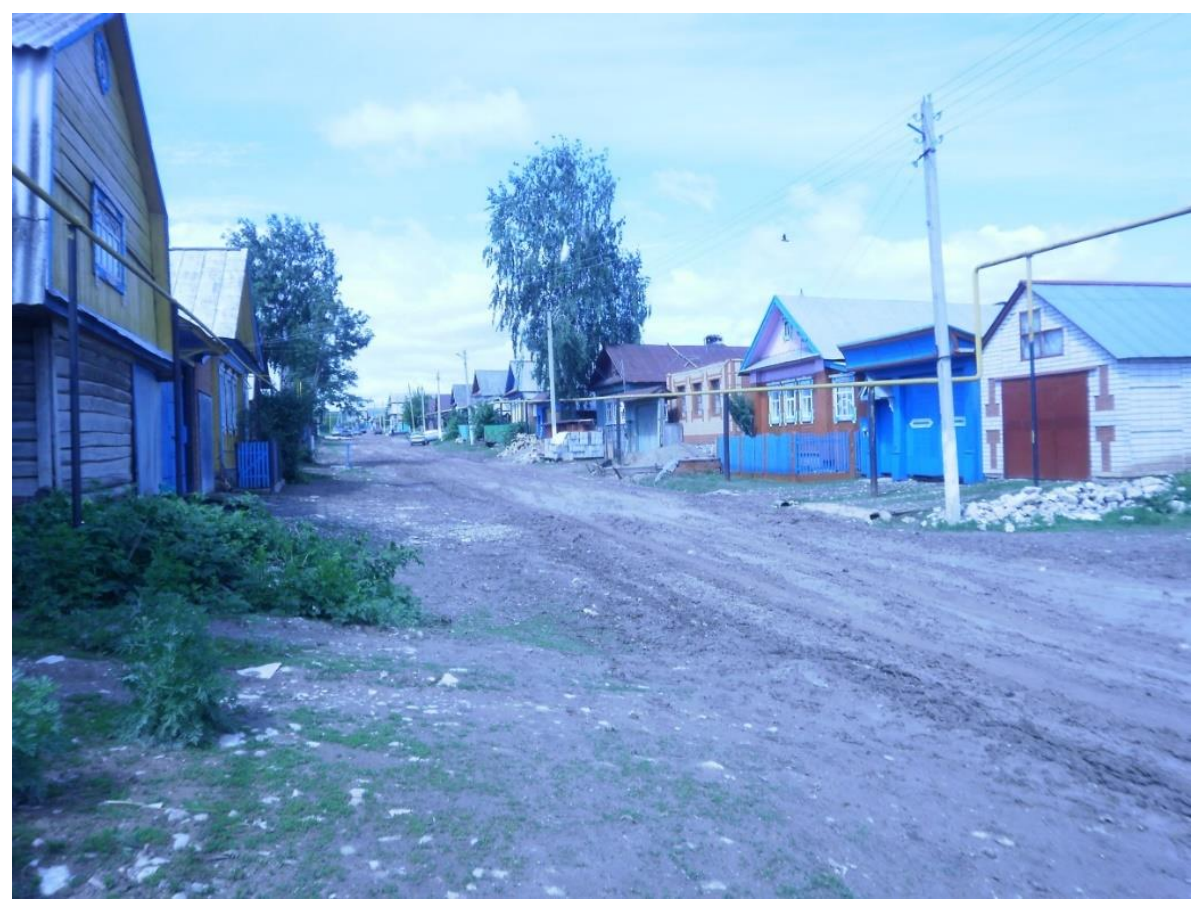

Görsel 1: Mamaşir köyünden bir görünüm.

Bizim bölgede bulunduğumuz dönemde Sabantuy Bayramı haziranın ilk pazar günü düzenlendi. Biz ise cumartesi gününden köye ulaştık. Küçük bir köy olmasına rağmen çok büyük bir kütüphaneye sahip olan Mamaşir'deki ilk günümüzü köyü gezerek ve köy kütüphanesini inceleyerek geçirdik.
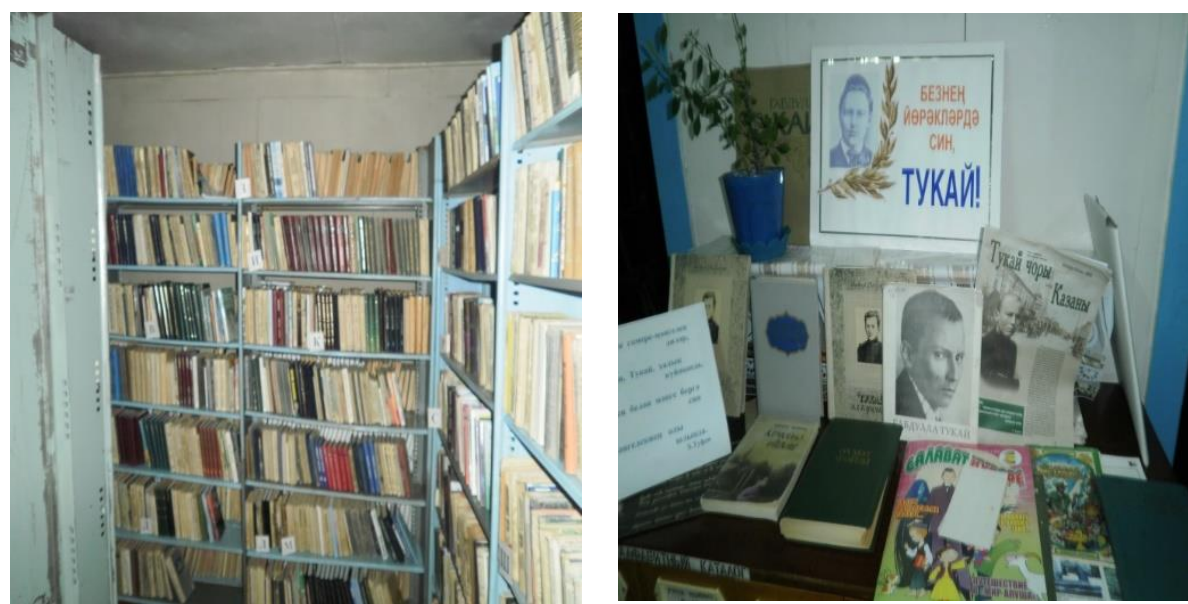
TATARISTAN'In KuKMARA RAYONU MAMAȘir KÖYÜNDE SABANTUy BAYRAMI • U
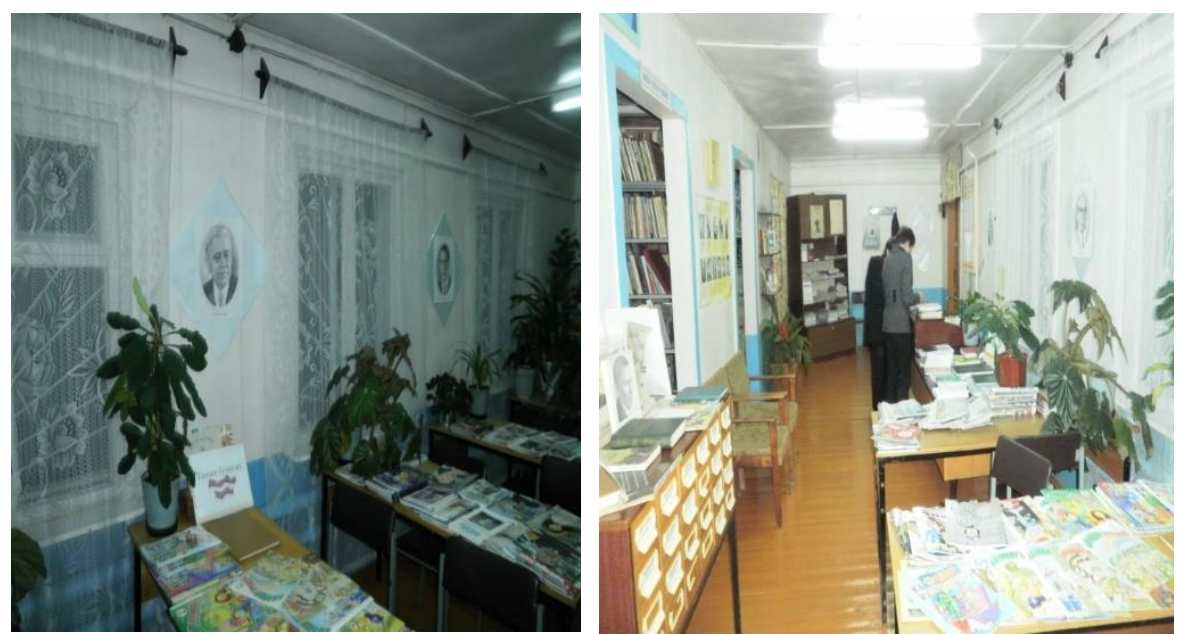

Görsel 2: Mamaşir köyü kütüphanesi

Pazar günü sabah erkenden Sabantuy Bayramı'nın yapılacağı meydana geçtik. Meydan, köyün dışında, Burets Nehri ile köy arasında konumlu düz bir çayırlıktı. Yukarıda ifade edildiği üzere meydan, izleyicilerin oturacağı tahta kalaslarla daire şeklinde çevrilmiş olup ortada ise çeşitli müsabakaların yapılması için bölmeler yapılmaktaydı. Meydanın bir köşesinde sunumların, konuşmaların yapıldı̆̆ 1 , yarışmacılara verilecek hediyelerin bulunduğu ve görevlilerin beklediği yer bulunmaktaydı. Bu bölmedeki görevlilerin kollarında, törende görevli olduklarını belirten kırmızı bir kurdele takılıydı.
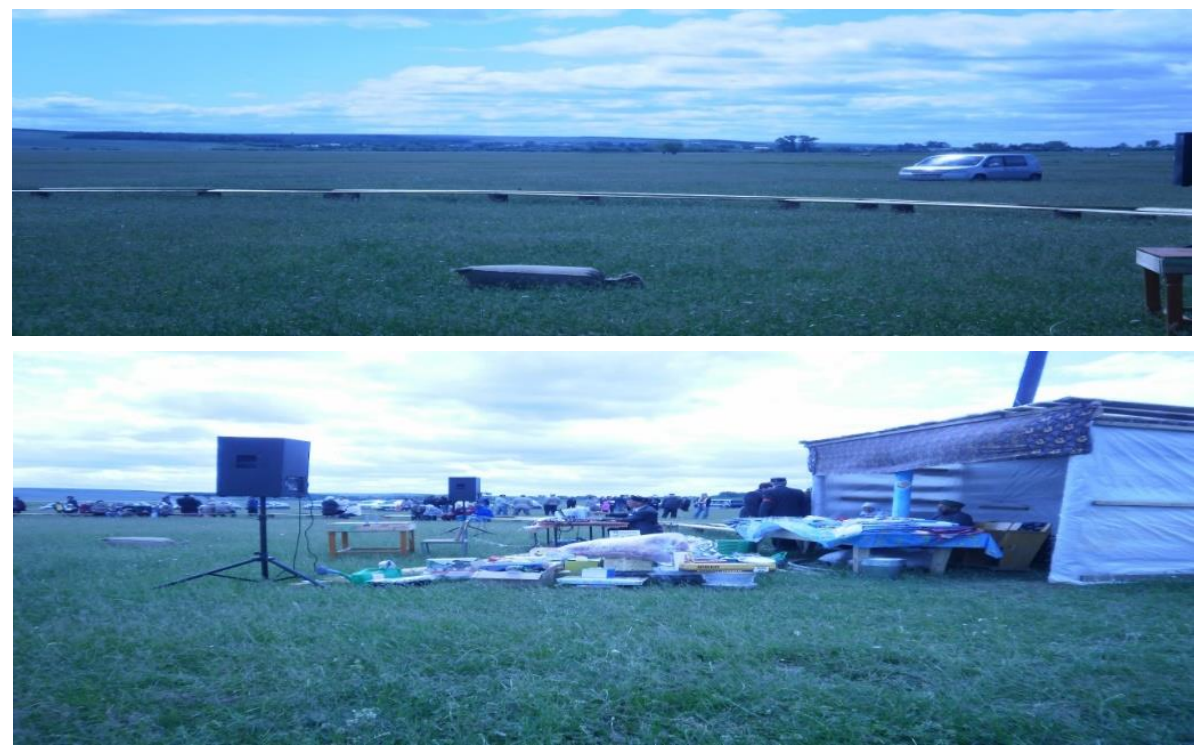

Görsel 3: Bayramın yapılacağı meydan (üstte), sunumların yapıldı̆ğ, hediyelerin bekletildiği ve görevlilerin beklediği bölüm-Kur'an okuyan ve açıllş̦ yapan imam (altta). 
Öğlene doğru köyden, çevre köylerden ve bizim gibi uzak şehirlerden gelenler meydana toplanmaya başladılar. Açılışı törene gelen imam, Kur'an tilaveti ve dua eşliğinde yaptı. İmama dua sonunda ücret olarak bir miktar para takdim edildi. Duanın ardından açılış konuşmaları yapıldı ve Tatar edibi, şairi ve bilim insanı olan Rife Rahman'ın Sabantuy için kaleme aldığı Sabantuy adlı şiirini okudu. Törenin ilerleyen bölümlerinde Rife Rahman, Unitırmın Dimen (Unuturum Deme) adlı hikâye kitabını imzalayarak törene katılanlara hediye etti.

Kutlamaların başlamasının ardından bir tarafta gençler karaoke yaparak Tatar türkülerini seslendirirken meydanda türlü yarışmalar düzenleniyordu. Meydanın ortasına serilen güreş minderinde çocuğundan gencine farklı yaş gruplarından erkeklerin katıldığı kuşak güreşi müsabakaları düzenlendi. Başta Kırım ve Kazan Tatarları olmak üzere Orta ve Kuzey Asyalı Türk topluluklarında çok yaygın olan kuşak güreşi özellikle bahar eğlencelerinde yapılan çok eski bir Türk sporudur. ${ }^{2}$ $\mathrm{Bu}$ güreşte, rakibinin sırtından geçirdiği kuşaklardan tutarak onu sırtüstü düşüren sporcu galip gelmektedir. Yarışmacılar minderde soyunmadan, sadece ayakkabılarını çıkararak mücadele etmektedirler.

Meydanda düzenlenen farklı bir yarışmada tahtadan yapılmış iptidai bir jimnastik beygiri üzerinde kadınlar ve erkekler, ellerindeki çuvallarla birbirlerine vurup dengelerini bozmaya ve düşürmeye çalışırlar. Dengesi bozulup tahta beygirden düşen yarışmacı yarışmayı kaybederken kazanan yarışmacı bir sonraki yarışmacı ile müsabakaya devam eder. Böylece en fazla rakibi düşüren yarışmacı yarışmayı kazanır ve ödülünü alır.

Kutlamalarda düzenlenen yarışmaların büyük bir çoğunluğu çocuklara ve gençlere yönelik olup çok azına yetişkinlerin katılımı söz konusudur. $\mathrm{Bu}$ uygulama, Sabantuy Bayramı'na bir çeşit çocuk ve gençlik bayramı hüviyeti kazandırmaktadır. $\mathrm{Bu}$ durumu, geleneklerinden uzaklaşma ve kültürel anlamda yozlaşma tehlikesi ile karşı karşıya kalan çocuk ve gençlere, geleneksel kültürlerini sevdirme çabası olarak yorumlayabiliriz. Yetişkinlerin katılımını gözlemlediğimiz yarışmalardan bazılarını ise halat çekme, ayaklarına palet giyen yarışmacıların meydanın ortasına salıverilen horozu yakalaması ve gözleri bağlanan kadınların ellerindeki uzun sopalarla bir yere saklanan nesneyi bulmaya çalışması olarak sıralayabiliriz.

\footnotetext{
${ }^{2}$ Geleneksel kuşak güreşi, Türk dünyasının ortak bir kültürel unsuru olarak Türkiye'de yaygın olarak yapılan bir güreş türüdür. Kuşak Güreşinin Türkmenistan'dan Kırım'a göç eden Kırım Türkleri tarafından Anadolu'ya getirildiği iddia edilmektedir. Türkiye'de ağırlıklı olarak Eskişehir ve civarında yaşayan Kırım Türkleri tarafından yapılmaktadır. Ayrıca mahalli organizasyonların yanı sıra her yıl Türkiye Geleneksel Spor Dalları Federasyonu tarafindan resmî müsabaka talimatına bağlı kalınarak muhtelif illerde ve tarihlerde Kuşak Güreşi Türkiye Şampiyonası düzenlenmektedir. Kırım'ın Kezlev bölgesinde, Romanya'nın Köstence ve Mangalya bölgelerinde her yıl organizasyonlar yapılmakta, Türkmenistan'da milli spor olarak yapılmaktadır. Ayrıca Tataristan'da, Yakutistan'da ve diğer Türk bölgelerinde de yapılmaktadır. Ayrıntılı bilgi için bk. (Güven 1992; Tüzün 2010; https://www.gsdf.gov.tr/tr/spor/kusak-guresi).
} 


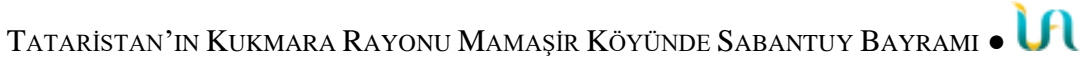

Yarışmalar içerisinde en dikkat çekici olanı tören meydanının yanına dikilen direğe tırmanıp bayrağı alma yarışmasıdır. Yaklaşık 30 metrelik direğe tırmanan kişi bayramın en prestijli hediyesi olan koçun da sahibi olacaktır.

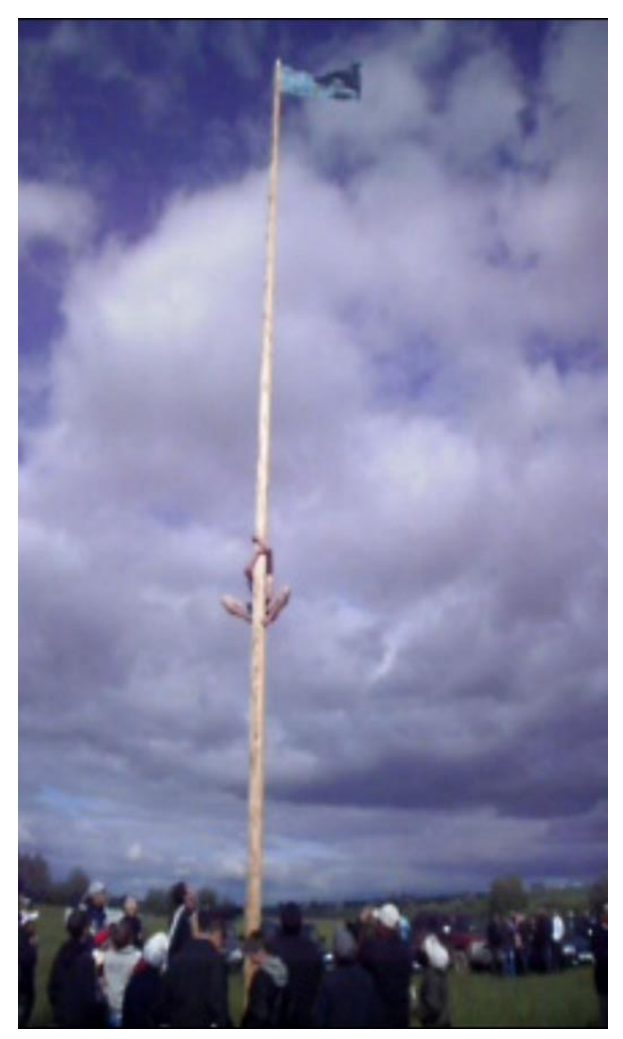

Görsel 4: Mamaşir Sabantuy törenlerinde direğe tırmanma yarışması (solda).

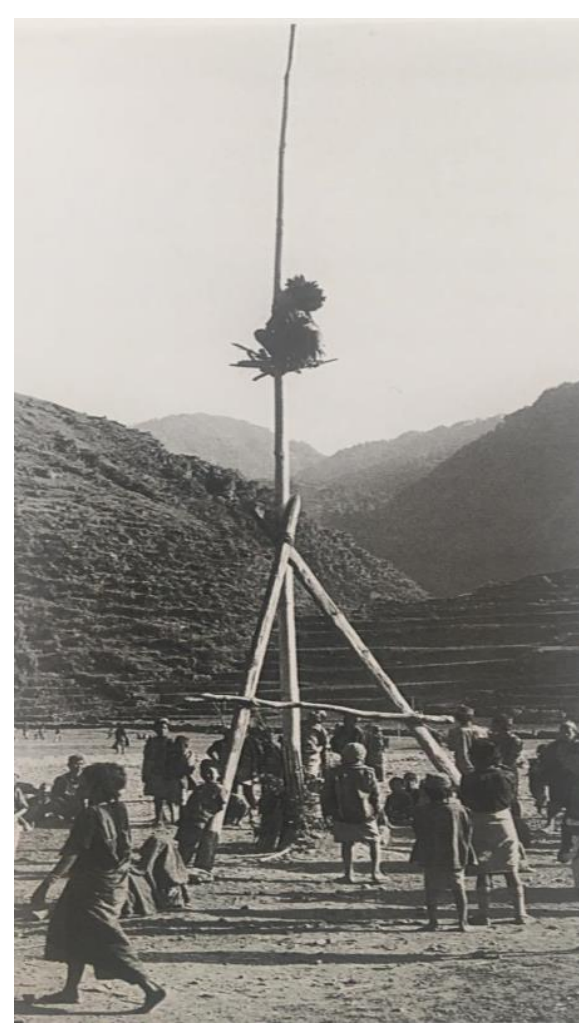

Görsel 5: Bir tören esnasında şamanın hayat ağacı vasitasılyla ruhlar dünyasına seyahati (sağda; Mihaly Hoppal, Avrasya'da Şamanlar, s. 22)

Sabantuy meydanının hemen yanına dikilen bu uzun direğin, Türklerin İslam öncesi inanç sistemlerine dayanan çok arkaik bir uygulamanın günümüze değin ulaşmış bir örneği olması kuvvetle muhtemeldir. Şamanist sistemde törenlerin en önemli unsurlarından biri; şamanın, mistik yolculuğunun bir safhası olarak yüce varlığa giden yolun simgesi olan direğe tırmanışıdır. Şaman, kozmik dünyaya bu direk vasıtasıyla ulaşır. Direk, göğe çıkış ve sihirli uçuş ile sıradan dünyayı aşıp tanrılar âlemine ulaşmanın özel bir yoludur. Bazen şaman, yine bu törenlerde göğün dokuz katmanını simgeleyen dokuz kayın ağacına kılıcıyla tırmanır. Dünyanın eksenini simgeleyen bu ağacın dünyanın merkezini tuttuğuna inanılır ve şamanların sırra ermelerinde mühim rol oynamaktadır (Eliade 2014: 166-167). Şamanların buna benzer kozmik yolculuğuna Sibirya ve Kuzey Asya 


\section{Uी•ÖMER AKSOY}

Şamanizm'inde de sık rastlanır. Direk ve benzeri biçimde yerle gök arasındaki iletişim ve ulaşımı sağladığına inanılan gök kuşağı, ağaç, merdiven, köprü, ip, ağaç, dă̆ gibi unsurları esasında yer-gök bağlantısının simgesel temsilcileri, Axis-Mundi'nin varyantları olarak kabul etmek mümkündür (Roux 2011: 597). Sabantuy Bayramı'nda karşımıza çıkan bu direk ve direğe tırmanarak tepesinde dikili olan bayrağı almak suretiyle kurbanlık koçu kazanma, eski şaman törenlerinin günümüz Tatar Türklerindeki kalıntıları olsa gerektir.
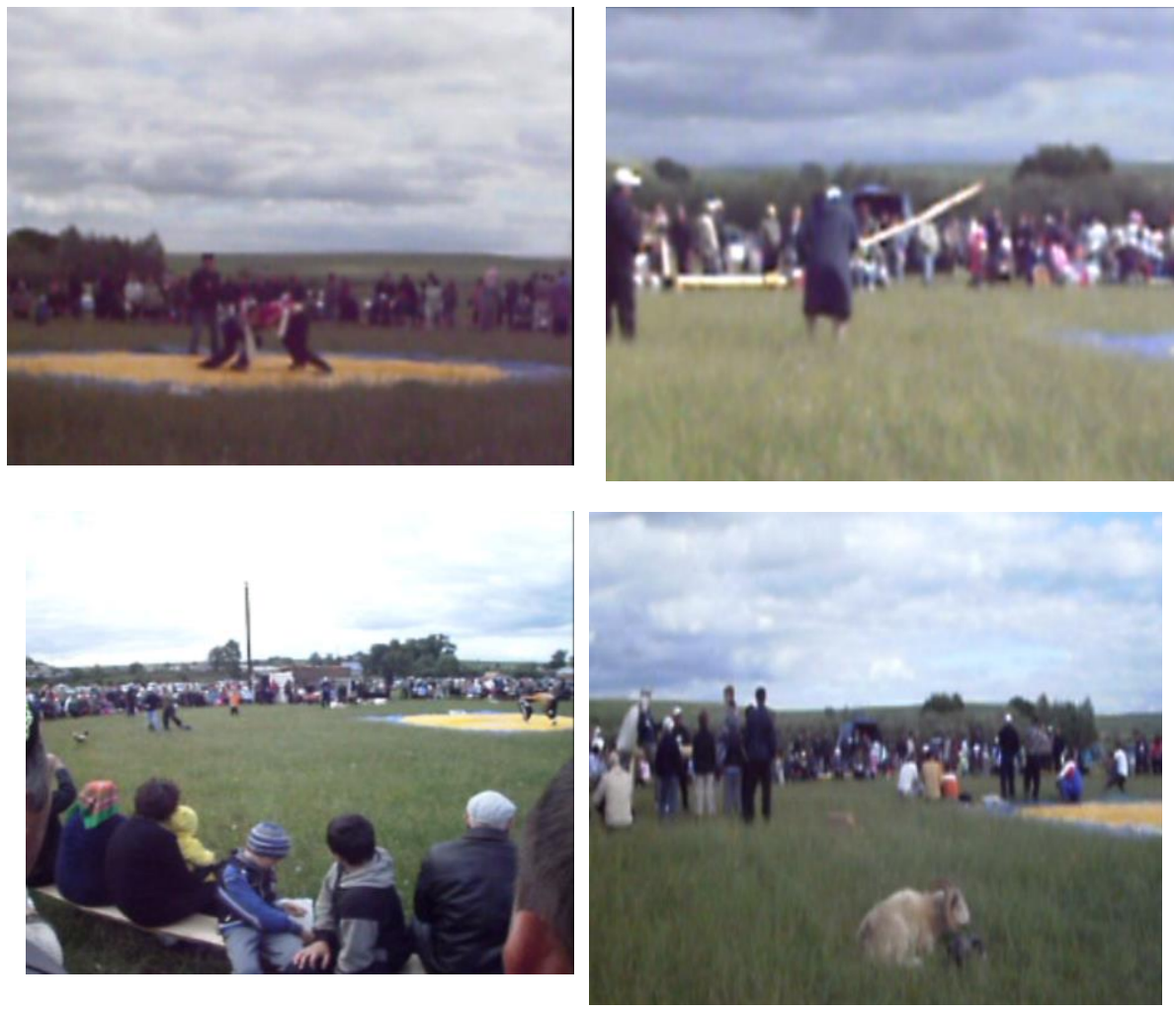

Görsel 4: Sol üstte kuşak güreşi yapan çocuklar, sağ üstte gözler bağll olarak hedefi vurma, sol altta ayaklarda palet ile horozu yakalama-kuşak güreşi, săg altta jimnastik beygirinde dengede durma-halat çekme ve ortada direğe tırmanma yarışmasını kazanana verilecek olan koç.

Yarıșmalar ve eğlenceler günün geç saatlerine kadar devam etmektedir. Akşama doğru sona eren kutlamalar, yerini gençlerin akşam eğlencesine bırakmaktadır. Akşam gerçekleştirilen eğlenceler bizim gözlemlediğimiz kadarıla büyük oranda modernize olmuş bir biçimde sürdürülmektedir. Evlerinde dinlenen gençler havanın kararması ile kutlama alanına yeniden dönmektedirler. Alana kurulan müzik sistemi, yanardöner disko topu ve spot 


\section{TATARISTAN'In KuKMARA RAYONu MAMașir KÖYÜNDE SABANTUY BAYRAMI • U}

lambası ile bir gece kulübü havası verilmiştir. Gençlerin eğlendiği müzikler ise İngilizce olup gece kulübü müzikleri tarzındadır. Gençlerin eğlencesi geç saatlere kadar sürmekte, bu eğlencelere ise orta ve ileri yaştaki insanlar katılmamaktadır. Akşam düzenlenen eğlencelerin de sadece gençlere yönelik olması yukarıda ifade ettiğimiz nedenlerle örtüşmektedir.

\section{Sonuç}

Sabantuy Bayramı'nın Tatar Türklerinin sosyal yaşantılarına yön veren birçok işlevi bulunmakla birlikte en önemli işlevi, Kazan Tatarlarının kültürel kimliğini oluşturan önemli unsurlardan birisi olması ile ilişkili olarak Tatar toplumunun millî-manevi birliğini, bütünlüğünü sağlamasıdır. Zira bu bayram vesilesiyle uzakta yaşayan akrabalar, dostlar yılda bir kez dahi olsa bir araya gelmekte ve bu insanlar arasındaki birlik ve bütünlük tesis edilmektedir. Bu noktada Sabantuy, Tatar etnik kimliği ile özdeşleşmiş ve millî bir sembole dönüşmüştür diyebiliriz. Mamaşir köyünde gözlemlediğimiz kadarıyla Sabantuy, geleneksel yapısından yavaş yavaş uzaklaşmakta, köyler ve farklı bölgeler arasındaki iletişimin artması ile yerel hususiyetlerini kaybedip tek tip bir kutlama hüviyetine bürünmektedir. Modern çağın imkânlarından da törenlerde azami derecede faydalanılmaktadır. Bunun en güzel örnekleri alana kurulan ses sistemi, çocuk ve gençlerin tören boyunca karaoke yaparak Tatar türküleri seslendirmeleri ve akşam eğlencelerinin tamamen kent kültürüne özgü bir biçimde tertip edilmesidir. Törenlerin resmî bir statü kazanması da bayram etkinliklerinin yerel statüsünü değiştirmiş ve Sabantuy'un resmî idareciler tarafindan organize edilen daha suni bir bayram kimliği kazanmasına neden olmuştur. Bu durum özellikle Kazan Sabantuy Bayramı şenliklerinde gözlemlediğimiz üzere kent merkezlerinde tertip edilen Sabantuy kutlamaları için geçerlidir. Burada tertiplenen törenlerde törene katılanlar tamamen izleyici konumunda olup düzenlenen resmî gösterileri izlemekle yetinmektedir. Mamaşir köyünde yaptığımız gözlemlere göre ise kırsal kesimlerde düzenlenen bayramlarda izleyici konumunda görünen köy ahalisi ve törene katılanlar, tüm yarışmaların bir katılımcısı, tören boyunca yapılan tüm aktivitelerin aktif birer unsuru kısacası bir izleyiciden öte törenlerin öznesi konumundadır.

\section{Kaynaklar}

Eliade, Mircea, Ebedî Dönüş Mitosu, Dergah Yay., İstanbul, 2017.

Eliade, Mircea, Şamanizm, İmge Kitabevi, İstanbul, 2014.

Frazer, James, Altın Dal I-II (Dinin ve Folklorun Kökleri), Pavel Yay., İstanbul, 2004.

Gılgamış Destanı (Çev. Sait Maden), Türkiye İş Bankası Kültür Yay., İstanbul, 2016.

Güven, Özbay, Türklerde Spor Kültürü, Türk Tarih Kurumu Basımevi, Ankara, 1992.

https://www.gsdf.gov.tr/tr/spor/kusak-guresi

Hoppal, Mihaly, Avrasya'da Şamanlar (Çev. Bülent Bayram- H. Şevket Çağatay Çapraz)YKY Yay., İstanbul, 2014. 
Nasırî, Kayum, "Poverya i Obryadı Kazanskih Tatar”. Zapiski Imperatorskogo Russkogo Geografiçeskogo Obşestva, Tom: VI, Vıp. II, 1880.

Roux, Jean-Poul, Türklerin ve Moğolların Eski Dini, Kabalcı Yay., Ankara, 2011.

Tatar Mifları (I. Kitap), Tataristan Kitap Neşr., Kazan, 1996.

Tüzün, Ahmet, Türk Dünyasında Ortak Sporlar, Gençlik ve Spor Genel Müdürlügü Yayın1, Ankara, 2010.

Urmançi, Fatih, Tatar Mifologiyası (Ensiklopedik Süzlek), Megarif Neşr. C. 3, Kazan, 2009.

Yavuz, Cemalettin, "Çuvaş Geleneksel Dünya Görüşünde Kutsal Düzenin İnşası: Timir Karta 'Demir Avlu' Uygulaması", Çuvaş, Dili, Edebiyatı ve Halkbilimi Çalışmaları (İvan Ya. Yakovlev'in 170. Doğum Yıl Dönümü Anısına), Nobel Bilimsel Eserler, Ankara, 2019, s. 193205.

Zaripova Çetin, Çulpan, "Kazan Tatarlarının Kültürel Kimliğinin Oluşumunda Sabantuy Bayramı”, 38. ICANAS Kongresi Bildirileri Kitabl, Ankara, 2017, s. 869-878.

\title{
ПРАЗДНИК САБАНТУЙ В СЕЛЕ МАМАШИР РАЙОНА КУКМАРА РЕСПУБЛИКИ ТАТАРСТАН
}

\begin{abstract}
Аннотация
Казанские татары - важнейшие представители древнетюркской цивилизации в Волго-Уральском регионе. Это тюркское племя, которое впервые приняло ислам. Приняв ислам, они стали важнейшими представителями и носителями тюрко-исламской цивилизации. Одним из самых известных традиционных праздников татар является праздник Сабантуй. Этот праздник, который отмечается с энтузиазмом каждый год, стал национальным символом для татар, которые борются за защиту своей традиционной культуры и национальной идентичности, особенно против насильственной аккультурационной политики Российской администрации. Истоки праздника Сабантуй восходят к периодам, предшествовавшим обращению казанских татар в ислам. Как следует из названия, он связан с сельскохозяйственной культурой. Можно связать архаические корни праздника с началом волжских булгар, которые перешли на оседлую жизнь в 8-м и 9-м веках и были предками Татар.

Сабантуй - это праздник, на котором татарский народ, особенно в сельской местности, организует и празднует приход лета под музыку и игры. Праздник Сабантуй разделен на две части: веселья и конкурсы, проводимые до и во время праздника. Первая часть включает в себя приготовления, сделанные перед праздником. Вторая часть состоит из мероприятий, проводимых в день праздника. Среди этих мероприятий есть много практик, которые мы можем связать со старыми тюркскими системами верований. Один из них заключается в защите территории, где проводится праздник, как один из этапов подготовки к празднику Сабантуй, путем рисования в круге плугом, чтобы защитить её от злых духов и различных негативных ситуаций. Среди празднований Сабантуя есть такие соревнования, как скачки, борьба, пение, перетягивание каната, восхождение на шест и поднятие тяжестей. По результатам гонок победителям
\end{abstract}


TATARISTAN'In KuKMARA RAYONU MAMAȘir KÖYÜNDE SABANTUY BAYRAMI • U

вручаются собранные до фестиваля подарки. Хотя праздник Сабантуй отмечается с большим сходством всеми татарскими племенами в разных регионах Татарстана, у этого праздника есть уникальные особенности, характерные для каждого региона. Эти различия были классифицированы татарскими исследователями как несколько вариантов.

Праздник Сабантуй имеет много функций, которые направляют общественную жизнь татаров. Важнейшая функция праздника заключается в том, что он является одним из важных элементов, составляющих культурную идентичность казанских татар и обеспечивающих национально-духовное единство и целостность татарской общины. По случаю этого праздника родственники и друзья, живущие далеко, собираются вместе хотя бы раз в год, и между этими людьми устанавливается единство и целостность. Поэтому праздник Сабантуй отождествился с татарской этнической идентичностью и превратился в национальный символ.

Как мы наблюдали в селе Мамашир, Сабантуй постепенно отдаляется от своей традиционной структуры, теряя свои местные особенности с увеличением связи между селами и различными регионами и принимая идентичность праздника, который отмечается одинаково по всей татарской стране. Возможности современной эпохи также максимально используются в церемониях. Церемонии, получившие официальный статус, также изменили местные особенности фестивальной деятельности и привели к тому, что она приобрела более искусственную фестивальную идентичность, организованную официальными учреждениями. Это особенно актуально для празднования Сабантуя, проводимого в центрах городов, как мы наблюдали во время празднования Казанского Сабантуя. Участники, проводимых здесь церемоний, полностью находятся в положении зрителей. В церемониях, проводимых в сельской местности, как и в селе Мамашир, сельские жители и те, кто присутствует на церемонии, являются участниками всех соревнований, активным элементом всех мероприятий во время церемонии и предметом церемоний.

В данном исследовании мы расскажем, как праздновали Сабантуй в селе Мамашир, которое мы посетили в рамках сборника исследований во время нашего пребывания в Татарстане. Предварительно мы дадим информацию о празднике Сабантуй, его общих характеристиках, отношениях со старыми тюркскими верованиями, значении этого праздника для татар и о том, каким символом он является в контексте культурной идентичности.

Ключевые слова: Сабантуй, казанские татары, Татарстан, культурные особенности, село Мамашир. 